\title{
In vitro Propagation of Plectranthus bourneae Gamble- An Endemic Red Listed Plant
}

\author{
R. Thaniarasu, T. Senthil Kumar ${ }^{*}$ and M.V. Rao \\ Department of Plant Science, Bharathidasan University, Tiruchirappalli- 620024, \\ Tamil Nadu, India
}

Key words: Plectranthus bourneae, Endemic plant, Lamiaceae, in vitro propagation, axillary bud.

\begin{abstract}
An efficient protocol of in vitro propagation of Plectranthus bourneae Gamble (Lamiaceae), a valuable medicinal important and endemic Red listed plant of Western Ghats, (Tamil Nadu, India) was standardized by improved shoot multiplication from axillary bud explant. An in vitro propagation system has been reconnoitered on MS with the effective concentration BA $(0.7 \mathrm{mg} / \mathrm{l})$ followed by a combination of BA $(0.7 \mathrm{mg} / \mathrm{l})$ and TDZ $(1.0 \mathrm{mg} / \mathrm{l})$ which promoted high number of shoots. The multiple shoot rate was enhanced further by adding AdS (50 mg/l). Beneficial shoot length was achieved when cultured on MS containing $\mathrm{GA}_{3}(0.5 \mathrm{mg} / \mathrm{l})$. Rooting was increased on MS augmented with IBA $(1.5 \mathrm{mg} / \mathrm{l})$. Micropropagated plants were acclimatized and the survival rate was $80 \%$. Acclimatized P. bourneae plants can be used as substitute alternative to natural populations. Using this protocol the propagated plants can be used for conservation strategies.
\end{abstract}

\section{Introduction}

The genus Plectranthus (Lamiaceae) comprises of about 300 species distributed through the tropical and warm regions of the Old World including Africa, India and Australia (Retief 2000). Plectranthus species are mostly soft, low growing, semi-succulent to succulent herbs or shrubs. These species are used for medicinal purposes against vomiting and nausea, to relive toothache, headache, sores, and burns, or as antiseptic, respiratory diseases (Rivera and Obon 1992a, b, Vera et al.

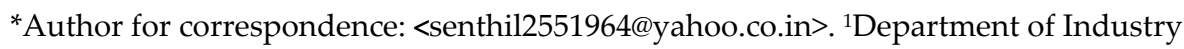
University Collaboration, Bharathidasan University, Tiruchirappalli- 620024, Tamil Nadu, India. 
1993, Bown 1995 and Lukhoba et al. 2006). The leaf extract of P. tenuiflorus is used to treat ear infections in Saudi Arabia (Abulfaith et al. 1987). P. cylindraceus has a pleasant aroma similar to commercial product Vicks (Marwah et al. 2007) and its leaves used as a body disinfectant and deodorant (Miller et al. 1998).

Plectranthus bourneae Gamble is an endemic plant species, has very restricted distribution only in the Western Ghats of Tamil Nadu, India. It is located in Pambar Shola, Kodaikanal, Tamil Nadu (Matthew 1993 and 1998). The plant is a well branched compact shrub (Fig. 1a). This species is in highly vulnerable status due to habitat destruction (Matthew 1999) and is included in the Red List of India (Nayar et al. 1990). Hence, a need for the development of alternative mass propagation system for this valuable species. Conventional enhancement methods and in vitro practices can be employed in further improvement of valuable Plectranthus. The conventional method of propagating this species is through seeds, but seed viability is very poor and low germinating limits its multiplication.

Plant tissue culture (PTC) offers a viable alternative method of propagation. It is used widely in the conservation of rare, endangered and medicinal plants and also commercial propagation (Rout et al. 2000). PTC constitutes a way to maintain available competent explants and free from contamination for use in vitro propagation and genetic transformation, besides being highly convenient for conservation of in vitro germplasm and cryopreservation. Very few reports are available on in vitro propagation of genus Plectranthus species such as $P$. ventiveroides (Sivasubramanian et al. 2002), P. barbatus (Thangavel et al. 2011). The aim of this study was to establish an efficient and reproducible in vitro propagation method from axillary bud of $P$. bourneae.

\section{Materials and Methods}

The plants of P. bourneae were collected from Pambar Shola of Kodaikanal hills $\left(10^{\circ} 5^{\prime}-10^{\circ} 25^{\prime} \mathrm{N}, 77^{\circ} 50^{\prime} \mathrm{E}\right.$ at an altitude of $\left.2020 \mathrm{~m}\right)$ in the Western Ghats of Tamil $\mathrm{Nadu}$, India and maintained in earthen pots in the glass house of Bharathidasan University, Tiruchirappalli under controlled condition $\left(26 \pm 2{ }^{\circ} \mathrm{C}\right.$ and $\left.\mathrm{RH} 70 \%\right)$. Axillary bud explants $(1 \mathrm{~cm})$ were washed under running tap water for $30 \mathrm{~min}$ and decontaminated with $70 \%$ ethanol for 30 s followed by $0.1 \%$ bavistin for 5 min and $3 \% \mathrm{NaOCl}$ for $2 \mathrm{~min}$. The explants were washed thoroughly with sterile distilled water minimum thrice. These sterilized explants were inoculated on culture medium.

MS was fortified with $30 \mathrm{~g} / \mathrm{l}$ sucrose (Himedia, India) and gelled with $0.8 \%$ (w/v) agar (Himedia, India), and the $\mathrm{pH}$ of the medium was adjusted to $5.7 \pm 0.2$

with $0.1 \mathrm{~N} \mathrm{NaOH}$ or $0.1 \mathrm{~N} \mathrm{HCl}$ after addition of the growth regulators. The 
medium was autoclaved at $121^{\circ} \mathrm{C}, 15 \mathrm{lb}$ pressure for $15 \mathrm{~min}$. All the cultures were maintained in aseptic growth room conditions $\left[26 \pm 2^{\circ} \mathrm{C}\right.$, under $16 / 8 \mathrm{hrs}$ light regime provided by cool white fluorescent light $\left(60 \mu \mathrm{mol}^{-2} \mathrm{sec}^{-1}\right.$ light intensity) and with 55 to $60 \%$ relative humidity].

Axillary bud explants were inoculated on MS medium containing different concentrations $(0.1 \mathrm{mg} / \mathrm{l}$ to $2.0 \mathrm{mg} / \mathrm{l})$ of cytokinins BA, Kn, TDZ and 2-iP alone and in combination for shoot initiation and multiplication. Data on frequency of shoot induction, multiple shoot induction, number and length of shoots were recorded after six weeks of culture.

Influence of various additives was studied after determining the optimum cytokinin combination level for the shoot bud induction to enhance the range of multiple shoots. Explants were cultured on MS supplemented with BA $(0.7 \mathrm{mg} / \mathrm{l})$ and TDZ (1.0 mg/l) along with different concentrations $(25,50,100 \mathrm{mg} / \mathrm{l})$ of adenine sulphate (AdS), glutamine, citric acid (CA) and yeast extract (YE) were used to study for the efficiency of shoot multiplication.

The microshoots $(\sim 1 \mathrm{~cm})$ obtained from the above experiments were transferred to shoot elongation medium (MS) containing $\mathrm{GA}_{3}(0.1,0.5,1.0,1.5$ and $2.0 \mathrm{mg} / \mathrm{l}$ ). MS devoid of plant growth regulators (PGRs) was used as control.

For rooting, in vitro raised shoots $(5-8 \mathrm{~cm})$ were harvested after six weeks and then inoculated on half strength MS supplemented with different levels (0.5, 1.0, 1.5 and $2.0 \mathrm{mg} / \mathrm{l}$ ) of IBA, IAA and NAA. Rooting was observed from 10 to 20 days. MS devoid of PGRs was used as control. Rooting percentage, number, and length were recorded after four weeks of culture. The rooted plantlets were washed and subsequently transferred to red soil: sand: coconut coir (1: 1: 1) mixture. Potted plants were covered with transparent polythene membrane under controlled growth chamber conditions of $26 \pm 2{ }^{\circ} \mathrm{C}, 16 \mathrm{hrs}$ photoperiod, 80$85 \%$ relative humidity and $60 \mu \mathrm{mol}^{-2} \mathrm{~s}^{-1}$ light intensity. They were frequently irrigated with sterile water every three days for four weeks. Plantlets were transplanted to the field.

All the experiments were conducted with a minimum of ten replicates per treatment and each experiment was repeated three times. DMRT was performed using SPSS version 16.0, mean and standard error (SE) followed by different letters were assigned to denote significance with $\mathrm{p}<0.05$.

\section{Result and Discussion}

Axillary bud explants were used for shoot initiation and multiplication (Fig. 1b). Shoot initiation was achieved in MS containing various concentrations of BA, Kn, 2-iP and TDZ (Fig. 1c). No regeneration was observed in control treatment. 
Among four cytokinins, BA $(0.7 \mathrm{mg} / \mathrm{l})$ produced 3.53 shoots/explant (Table 1$)$. The BA higher than $0.7 \mathrm{mg} / \mathrm{l}$ reduced shoot number and frequency. For bud break $\mathrm{Kn}$ was found best and BA responded better than $\mathrm{Kn}$ in terms of shoot

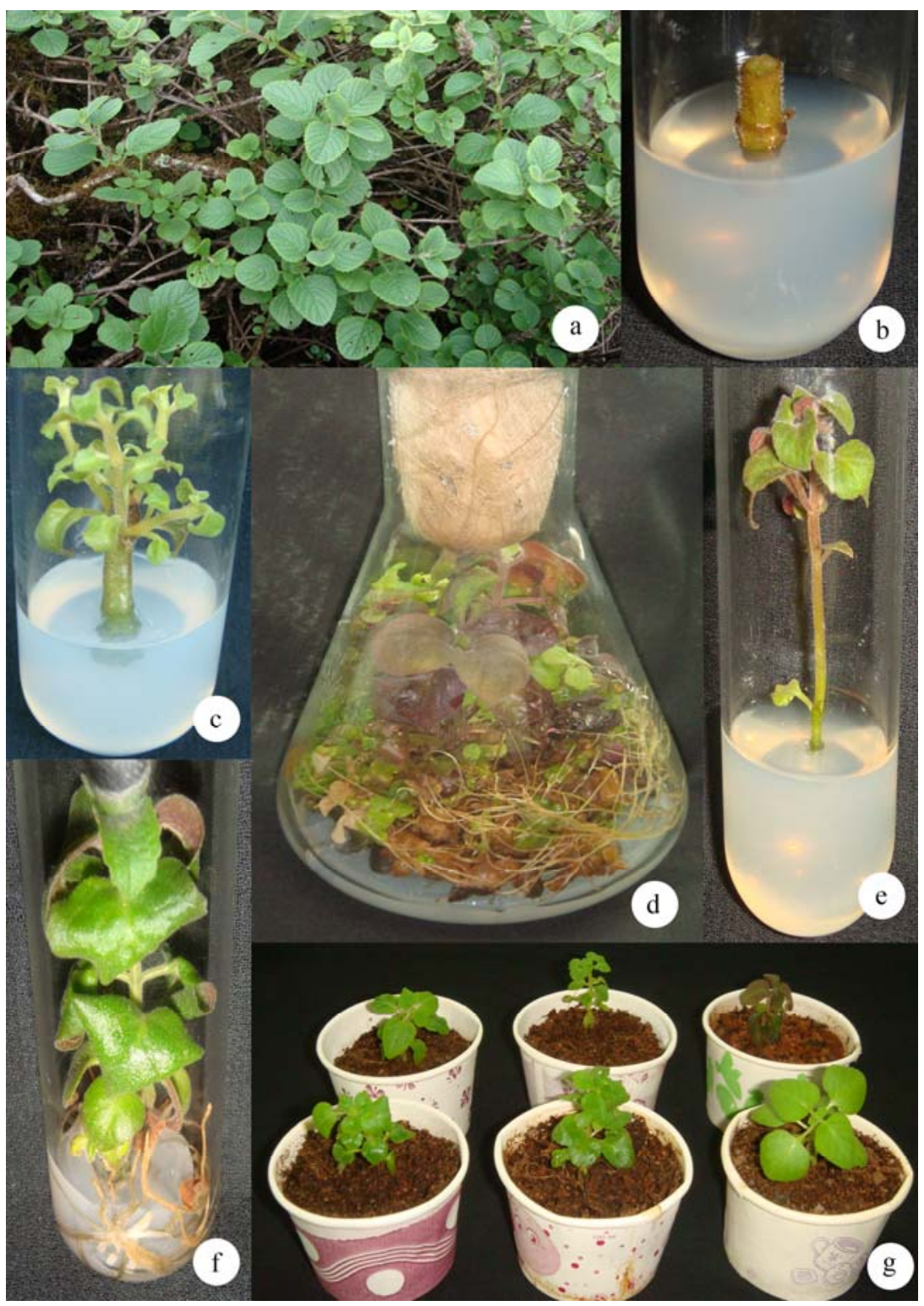

Fig. 1. In vitro propagation of P. bourneae (a) Habitat of P. bourneae, (b) Axillary bud explant. (c) Initiation of shoots from axillary bud explant. (d) Multiple shoots on MS with BA $0.7 \mathrm{mg} / \mathrm{l}+\mathrm{TDZ} 1.0 \mathrm{mg} / \mathrm{l}+$ AdS $50 \mathrm{mg} / \mathrm{l}$. (e) Shoot elongation. (f) Root formation on half strength of MS with IBA $1.5 \mathrm{mg} / \mathrm{l}$. (g) Hardened in vitro plant. 
Table 1. Shoot bud initiation from axillary bud explants of $P$. bourneae on MS supplemented with cytokinins, after 45 days.

\begin{tabular}{|c|c|c|c|}
\hline $\begin{array}{c}\text { Cytokinin } \\
(\mathrm{mg} / \mathrm{l})\end{array}$ & Shoots/explant & $\begin{array}{l}\text { Shoot length } \\
(\mathrm{cm})\end{array}$ & $\begin{array}{l}\text { Frequency of } \\
\text { response (\%) }\end{array}$ \\
\hline \multicolumn{4}{|l|}{ BA } \\
\hline 0.1 & $1.87 \pm 0.12^{\mathrm{de}}$ & $0.70 \pm 0.09 j$ & $42.85 \pm 2.63^{\mathrm{hi}}$ \\
\hline 0.5 & $2.87 \pm 0.47^{b}$ & $1.27 \pm 0.15^{\mathrm{de}}$ & $59.18 \pm 3.72^{\mathrm{de}}$ \\
\hline 0.7 & $3.53 \pm 0.46^{\mathrm{a}}$ & $3.08 \pm 0.37^{a}$ & $87.75 \pm 2.85^{\mathrm{a}}$ \\
\hline 1.0 & $2.37 \pm 0.18^{b c d}$ & $1.50 \pm 0.25^{\mathrm{cd}}$ & $73.46 \pm 3.72^{\mathrm{bc}}$ \\
\hline 1.5 & $1.75 \pm 0.16^{\mathrm{ef}}$ & $1.58 \pm 0.20^{\mathrm{bc}}$ & $67.34 \pm 2.08^{\mathrm{bc}}$ \\
\hline 2.0 & $1.37 \pm 0.18 \mathrm{~g}$ & $1.55 \pm 0.09 \mathrm{bc}$ & $51.02 \pm 2.88 f^{g h}$ \\
\hline \multicolumn{4}{|l|}{$\mathrm{KN}$} \\
\hline 0.1 & $1.87 \pm 0.12^{\mathrm{de}}$ & $2.07 \pm 0.13^{\mathrm{b}}$ & $57.14 \pm 3.11^{\mathrm{de}}$ \\
\hline 0.5 & $1.87 \pm 0.12^{\mathrm{de}}$ & $1.72 \pm 0.17^{\mathrm{bc}}$ & $65.30 \pm 2.24^{\text {cde }}$ \\
\hline 0.7 & $2.00 \pm 0.00^{\mathrm{cd}}$ & $1.88 \pm 0.17^{\mathrm{bc}}$ & $61.22 \pm 2.08^{\mathrm{de}}$ \\
\hline 1.0 & $2.50 \pm 0.26^{\mathrm{bc}}$ & $1.84 \pm 0.14^{\mathrm{bc}}$ & $77.55 \pm 2.24^{\mathrm{ab}}$ \\
\hline 1.5 & $2.00 \pm 0.00^{\text {cde }}$ & $1.77 \pm 0.17^{\mathrm{bcd}}$ & $63.26 \pm 2.88^{\text {cde }}$ \\
\hline 2.0 & $2.00 \pm 0.00^{\text {cde }}$ & $1.61 \pm 0.09^{\mathrm{bcd}}$ & $48.97 \pm 2.88^{\mathrm{gh}}$ \\
\hline \multicolumn{4}{|l|}{$2 \mathrm{iP}$} \\
\hline 0.1 & $1.75 \pm 0.16^{\mathrm{ef}}$ & $0.97 \pm 0.16^{\mathrm{hi}}$ & $22.44 \pm 3.26^{\mathrm{k}}$ \\
\hline 0.5 & $1.37 \pm 0.18 \mathrm{~g}$ & $0.95 \pm 0.07 \mathrm{hi}$ & $32.65 \pm 4.08^{\mathrm{ij}}$ \\
\hline 0.7 & $1.62 \pm 0.18^{\mathrm{fg}}$ & $1.20 \pm 0.08^{\mathrm{ef}}$ & $32.65 \pm 2.63^{i j}$ \\
\hline 1.0 & $2.00 \pm 0.00^{\mathrm{cd}}$ & $0.95 \pm 0.07^{\mathrm{hi}}$ & $34.69 \pm 2.88^{\mathrm{ij}}$ \\
\hline 1.5 & $1.62 \pm 0.18^{\mathrm{fg}}$ & $1.07 \pm 0.11^{\mathrm{gh}}$ & $36.73 \pm 2.88^{i}$ \\
\hline 2.0 & $1.75 \pm 0.25^{\mathrm{ef}}$ & $1.04 \pm 0.15^{\mathrm{gh}}$ & $24.48 \pm 2.63^{j \mathrm{k}}$ \\
\hline \multicolumn{4}{|l|}{ TDZ } \\
\hline 0.1 & $1.62 \pm 0.18 \mathrm{fg}$ & $1.24 \pm 0.14^{\mathrm{de}}$ & $55.10 \pm 2.04^{\mathrm{efg}}$ \\
\hline 0.5 & $2.25 \pm 0.16^{\mathrm{de}}$ & $0.94 \pm 0.16^{\mathrm{ij}}$ & $59.18 \pm 3.72^{\text {de }}$ \\
\hline 0.7 & $1.87 \pm 0.12^{\mathrm{de}}$ & $1.07 \pm 0.12^{\mathrm{fg}}$ & $65.30 \pm 2.88^{\text {cde }}$ \\
\hline 1.0 & $2.62 \pm 0.26^{\mathrm{bc}}$ & $1.28 \pm 0.08^{\mathrm{de}}$ & $69.38 \pm 2.85^{\mathrm{bc}}$ \\
\hline 1.5 & $2.37 \pm 0.26^{\mathrm{bcd}}$ & $1.05 \pm 0.17^{\mathrm{gh}}$ & $65.30 \pm 2.88^{\text {cde }}$ \\
\hline 2.0 & $2.12 \pm 0.12^{\text {cde }}$ & $1.42 \pm 0.04^{\mathrm{cd}}$ & $48.97 \pm 2.88 \mathrm{~g}$ \\
\hline
\end{tabular}

initiation and multiplication. Comparing the number of shoots using optimal concentration of $\mathrm{Kn}(1.0 \mathrm{mg} / \mathrm{l})$ with that using BA (Table 1), it was clear that fewer shoots were produced by using Kn. BA was the most effective to overcome apical dominance, and promote multiple shoot formation (Fatima et al. 2012). TDZ induced the formation of shoots at all concentration. Moreover, the proportion of stunted shoots increased with increased concentration. When 2-iP 
was used alone, a slight basal callusing was observed with a low regeneration frequency. Similar result was also reported by Khattab (2011) and Rafique Ahmed et al. (2013). In the present study, optimal concentration of $0.7 \mathrm{mg} / \mathrm{l} \mathrm{BA}$ was selected further and used in combination with $\mathrm{Kn}, 2-\mathrm{iP}$ and TDZ to enhance shoot multiplication rate. Similarly many workers reported stimulatory effect of BA on multiple shoot induction in other medicinally important plants species such as Salacia reticulata (Dhanasri et al. 2013) and Decalepis hamiltonii (Sharma et al. 2014).

Values represent means \pm SE. Values followed by the same letter are not significantly different at $\mathrm{p}<0.05$ according to DMRT. In this study, 2-iP produced lower shoot regeneration than other combinations. High shoot formation $(12.14 \pm 0.55)$ was observed in the concentration of BA $(0.7 \mathrm{mg} / \mathrm{l})$ and TDZ $(1.0 \mathrm{mg} / \mathrm{l})$ and it can be attributed to the synergistic effect of the combination (Table 2). The combination of BA and TDZ showed an increase in shoot numbers and decreased at higher concentration. It is widely documented by many researchers that TDZ is equal in effective than BA (Tawfik and Mohamed 2005, Nagar et al. 2015). The result produced on BA and TDZ combination was vastly greater than any other cytokinin single or combination. BA combined with $\mathrm{Kn}$ showed appropriate result of shoot multiplication, however, it was not as efficient as TDZ (Table 2). Frequently, cytokinins have a major role on plant development, such as the regulation of shoot development and multiplication and the improvement of cell division and expansion (Mok and Mok 2001).

Effect of additives like adenine sulphate, glutamine, citric acid, yeast extract in different concentrations of 25 to $100 \mathrm{mg} / \mathrm{l}$ were tested in combination with BA $(0.7 \mathrm{mg} / \mathrm{l})$ and TDZ $(1.0 \mathrm{mg} / \mathrm{l})$ to enhance in vitro shoot multiplication after determining optimal cytokinins level for shoot proliferation, multiplication and quality of shoots. The medium supplemented with AdS showed significant increase in the rate of shoot multiplication. Benefits are often only observed when adenine is administered together with a cytokinin (George et al. 2007). In our study, we found $50 \mathrm{mg} / \mathrm{l}$ of AdS was highly effective for enhancing shoot multiplication rate $(19.57 \pm 0.64)$ (Table 3, Fig. 1d). AdS can augment cell growth and shoot multiplication feasibly by performing as organic nitrogen source and or as precursor for natural cytokinin production. The stimulative role of AdS in shoot multiplication has been reported by many workers (Husain et al. 2008, Siwach et al. 2011). Nitrogen is the vital factor for appropriate plant growth and development.

The efficacy of organic nitrogen source like glutamine exhibit moderate number of shoots $(15.14 \pm 0.70)$ due to its stimulative effect, glutamine directly 
involved in the assimilation of ammonia. The nitrates and ammonium salts have been widely used for in vitro studies as nitrogen source, many reports suggest the use of adenines and amino acids can adjust the nitrogen utilization of in vitro growth regulation in many plant species (Shrivastava et al. 2008, Jayakumar et al. 2013). CA controls browning of culture medium and also plays a significant role in the multiplication of shoots in many plants. Accordingly, their ability on shoot multiplication was examined. CA in combination with BA $(0.7 \mathrm{mg} / \mathrm{l})+\mathrm{TDZ}(1.0$ $\mathrm{mg} / \mathrm{l})$ enhance shoot multiplication frequency and number of shoot production per explant was lower when compared to that of AdS and glutamine (Table 3). YE did not significantly improve the shoot development frequency, shoot number and shoot length. At higher concentration of YE browning of tissues resulted with the suppression of shoot proliferation (Sridhar et al. 2014). The shoots $(1-2 \mathrm{~cm})$ were excised from the axillary bud shoot clusters raised from BA $(0.7 \mathrm{mg} / \mathrm{l})$, TDZ $(1.0 \mathrm{mg} / \mathrm{l})$ and AdS (50 mg/l) combination, and were elongated on MS media with various concentrations of $\mathrm{GA}_{3}(0.1-2.0 \mathrm{mg} / \mathrm{l})$.

Among various combinations used $\mathrm{GA}_{3} 0.5 \mathrm{mg} / \mathrm{l}$ produced maximum shoot length $(5.87 \pm 0.31 \mathrm{~cm})$ and number of leaves per shoot $(11.70 \pm 0.15)$. When the $\mathrm{GA}_{3}$ concentration was increased, the shoot length also increased up to the optimum level $(1.5 \mathrm{mg} / \mathrm{l})$ afterwards it decreased with further increased. However, shoot length and frequency considerably decreased in higher concentration of $\mathrm{GA}_{3}$ (Table 4, Fig. 1e). Similar results also were reported in Graptophyllum pictum (Justin and Wilson 2010) and Andrographis echoides (Hemalatha and Vadivel 2010). Following this experiment elongated shoots were transferred to root induction medium.

Elongated shoots $(4-6 \mathrm{~cm})$ were excised and placed on half and full strength MS supplemented with various concentrations of IBA, IAA and NAA for root induction. Full strength MS containing auxins showed very poor response in rooting, but half strength MS supplemented with auxins were achieved well developed roots within 20 days. All the microcuttings show rooting response against all the three auxins tested. Half strength MS fortified with different concentrations of IBA $(1.5 \mathrm{mg} / \mathrm{l})$ had radical effect and their supremacy was absolute for all the other treatments, followed by different concentrations of NAA and IAA, respectively. The current results were further confirmed by the previous findings of Trichosanthes dioica (Awal et al. 2005) and Ginger (Rajani and Patil 2009), who suggested IBA as the best auxin for root induction and development in various plant species. Among the different auxins, IBA was found to be most effective for root induction where NAA gave 
moderate number of roots. The highest number of roots per shoot $(12.85 \pm$ $0.82)$, root length per shoot $(5.11 \pm 0.28)$ and high frequency was obtained in IBA $(91.83 \pm 4.24)$. Further increase in auxin concentration showed a decrease in the frequency, number of roots and root length (Table 5, Fig. 1f).

Table 2. Shoot multiplication from shoot buds initiated of axillary bud explants of P.bourneae on MS medium supplemented with BA $(0.7 \mathrm{mg} / \mathrm{l})$ and other cytokinins, after 45 days.

\begin{tabular}{cccc}
\hline $\begin{array}{c}\text { Growth } \\
\text { regulators } \\
(\mathrm{mg} / \mathrm{l})\end{array}$ & $\begin{array}{c}\text { Shoots/ } \\
\text { explant }\end{array}$ & $\begin{array}{c}\text { Shoot length } \\
(\mathrm{cm})\end{array}$ & $\begin{array}{c}\text { Frequency of } \\
\text { response }(\%)\end{array}$ \\
\hline $\mathbf{K n}$ & & & \\
0.5 & $4.14 \pm 0.26^{\mathrm{cd}}$ & $2.92 \pm 0.31^{\mathrm{ab}}$ & $55.10 \pm 2.04^{\mathrm{ef}}$ \\
1.0 & $6.42 \pm 0.36^{\mathrm{b}}$ & $3.22 \pm 0.24^{\mathrm{a}}$ & $71.42 \pm 3.11^{\mathrm{bc}}$ \\
1.5 & $4.14 \pm 0.40^{\mathrm{cd}}$ & $2.34 \pm 0.13^{\mathrm{cd}}$ & $53.06 \pm 2.63^{\mathrm{ef}}$ \\
2.0 & $3.71 \pm 0.28^{\mathrm{d}}$ & $2.55 \pm 0.21^{\mathrm{bc}}$ & $48.97 \pm 2.88^{\mathrm{f}}$ \\
TDZ & & & \\
0.5 & $7.85 \pm 1.14^{\mathrm{b}}$ & $1.74 \pm 0.12^{\mathrm{de}}$ & $63.26 \pm 2.88^{\mathrm{cd}}$ \\
1.0 & $12.14 \pm 0.55^{\mathrm{a}}$ & $1.90 \pm 0.15^{\mathrm{de}}$ & $85.71 \pm 3.11^{\mathrm{a}}$ \\
1.5 & $6.71 \pm 1.45^{\mathrm{b}}$ & $1.60 \pm 0.11^{\mathrm{e}}$ & $73.46 \pm 3.72^{\mathrm{b}}$ \\
2.0 & $6.00 \pm 0.61^{\mathrm{b}}$ & $1.54 \pm 0.05^{\mathrm{e}}$ & $59.18 \pm 3.72^{\mathrm{de}}$ \\
$2 \mathbf{i P}$ & & & \\
0.5 & $2.85 \pm 0.26^{\mathrm{d}}$ & $2.35 \pm 0.30^{\mathrm{cd}}$ & $40.81 \pm 3.73^{\mathrm{h}}$ \\
1.0 & $2.71 \pm 0.28^{\mathrm{d}}$ & $2.12 \pm 0.20^{\mathrm{cd}}$ & $38.77 \pm 2.08^{\mathrm{h}}$ \\
1.5 & $3.28 \pm 0.28^{\mathrm{d}}$ & $1.64 \pm 0.23^{\mathrm{e}}$ & $46.93 \pm 2.08^{\mathrm{gh}}$ \\
2.0 & $3.00 \pm 0.30^{\mathrm{d}}$ & $1.61 \pm 0.23^{\mathrm{e}}$ & $42.85 \pm 2.40^{\mathrm{gh}}$ \\
\hline
\end{tabular}

Values represent means \pm SE. Values followed by the same letter are not significantly different at $\mathrm{p}<0.05$ according to DMRT.

Plantlets were removed from the rooting medium, washed properly under running tap water to remove any adherent gel and transferred to paper cups (6.5 $\mathrm{cm}$ diameter) containing sterilized soil (Fig. 1g). Paper cups were covered with polythene bag and kept for 15 days. Small holes were made on the polythene bag to reduce the relative humidity. Slowly the width of the holes was increased until the relative humidity inside the polythene bag and outside the chamber comes to equal. The plants were maintained under controlled temperature $\left(25 \pm 2^{\circ} \mathrm{C}\right)$ with $90 \%$ humidity. Finally polythene bags were removed and the pots were kept in 
Table 3. Shoot multiplication from shoot buds initiated from axillary bud explants of $P$. bourneae on MS supplemented with BA $(0.7 \mathrm{mg} / 1)$, TDZ (1.0 $\mathrm{mg} / \mathrm{l})$ and additives, after 45 days.

\begin{tabular}{cccc}
\hline $\begin{array}{c}\text { Additives } \\
(\mathrm{mg} / \mathrm{l})\end{array}$ & $\begin{array}{c}\text { Shoot length } \\
(\mathrm{cm})\end{array}$ & $\begin{array}{c}\text { Shoots/ } \\
\text { explants }\end{array}$ & $\begin{array}{c}\text { Frequency of } \\
\text { response }(\%)\end{array}$ \\
\hline $\begin{array}{c}\text { Adenine sulphate } \\
25\end{array}$ & $1.10 \pm 0.24^{\mathrm{c}}$ & $10.42 \pm 0.42^{\mathrm{d}}$ & $66.00 \pm 1.63^{\mathrm{bc}}$ \\
50 & $1.94 \pm 0.31^{\mathrm{a}}$ & $19.57 \pm 0.64^{\mathrm{a}}$ & $92.00 \pm 1.33^{\mathrm{a}}$ \\
100 & $1.11 \pm 0.20^{\mathrm{c}}$ & $9.85 \pm 0.50 \mathrm{~d}^{\mathrm{e}}$ & $64.00 \pm 1.63^{\mathrm{c}}$ \\
Glutamine & & & \\
25 & $1.00 \pm 0.13^{\mathrm{c}}$ & $8.71 \pm 0.35^{\mathrm{ef}}$ & $43.00 \pm 1.52^{\mathrm{ef}}$ \\
50 & $1.90 \pm 0.04^{\mathrm{a}}$ & $15.14 \pm 0.70^{\mathrm{b}}$ & $70.00 \pm 1.49^{\mathrm{b}}$ \\
100 & $1.45 \pm 0.40^{\mathrm{b}}$ & $13.42 \pm 0.68^{\mathrm{c}}$ & $58.00 \pm 1.33^{\mathrm{d}}$ \\
Citric acid & & & \\
25 & $1.15 \pm 0.15^{\mathrm{c}}$ & $9.57 \pm 0.48 \mathrm{~d}^{\mathrm{e}}$ & $32.00 \pm 1.33^{\mathrm{g}}$ \\
50 & $1.12 \pm 0.26^{\mathrm{c}}$ & $7.57 \pm 0.20^{\mathrm{fg}}$ & $43.00 \pm 1.52^{\mathrm{ef}}$ \\
100 & $0.67 \pm 0.20^{\mathrm{d}}$ & $7.28 \pm 0.52^{\mathrm{gh}}$ & $42.00 \pm 1.33^{\mathrm{f}}$ \\
Yeast extract & & & \\
25 & $1.58 \pm 0.23^{\mathrm{b}}$ & $7.14 \pm 0.26^{\mathrm{gh}}$ & $33.00 \pm 1.52^{\mathrm{g}}$ \\
50 & $1.45 \pm 0.19^{\mathrm{b}}$ & $6.00 \pm 0.30^{\mathrm{hi}}$ & $47.00 \pm 1.52^{\mathrm{e}}$ \\
100 & $1.14 \pm 0.26^{\mathrm{b}}$ & $5.57 \pm 0.29 \mathrm{j}$ & $34.00 \pm 1.63^{\mathrm{g}}$ \\
\hline
\end{tabular}

Values represent means \pm S.E. Values followed by the same letter are not significantly different at $\mathrm{p} \leq 0.05$ according to DMRT.

Table 4. Effect of different concentrations of $\mathrm{GA}_{3}$ on in vitro shoot elongation.

\begin{tabular}{cccc}
\hline $\begin{array}{c}\text { Growth regulator } \\
\mathrm{GA}_{3}(\mathrm{mg} / \mathrm{l})\end{array}$ & $\begin{array}{c}\text { No. of nodes/ } \\
\text { explant }\end{array}$ & Shoot length $(\mathrm{cm})$ & $\begin{array}{c}\text { No. of leaves/ } \\
\text { explant }\end{array}$ \\
\hline 0.1 & $3.60 \pm 0.16^{\mathrm{c}}$ & $2.40 \pm 0.16^{\mathrm{d}}$ & $7.70 \pm 0.48^{\mathrm{c}}$ \\
0.5 & $7.60 \pm 0.16^{\mathrm{a}}$ & $5.87 \pm 0.31^{\mathrm{a}}$ & $11.70 \pm 0.15^{\mathrm{a}}$ \\
1.0 & $5.60 \pm 0.16^{\mathrm{b}}$ & $4.67 \pm 0.27^{\mathrm{b}}$ & $9.40 \pm 0.30^{\mathrm{b}}$ \\
1.5 & $3.70 \pm 0.15^{\mathrm{c}}$ & $3.92 \pm 0.19^{\mathrm{c}}$ & $7.60 \pm 0.16^{\mathrm{c}}$ \\
2.0 & $2.50 \pm 0.16^{\mathrm{d}}$ & $2.27 \pm 0.15^{\mathrm{d}}$ & $5.80 \pm 0.13^{\mathrm{d}}$ \\
\hline
\end{tabular}

Values represent means \pm SE. Values followed by the same letter are not significantly different at $\mathrm{p}<0.05$ according to DMRT.

diffused light for 15 days and finally plants were shifted to pots for acclimatization and they were exposed to the sunlight. The percentage of plant survival was calculated after two months. The in vitro rooted plantlets were 
successfully acclimatized with around $80 \%$ survival rate. The regenerated plants did not show any noticeable morphological variations when compared with mother plant. Frequent observations were made to inspect drying of plant parts and they were slowly introduced to a glass house environment.

Table 5. Rooting of shoots obtained from axillary bud explants of P.bourneae on half strength MS medium supplemented with auxins, after 20 days. [I

\begin{tabular}{cccc}
\hline Auxins $(\mathrm{mg} / \mathrm{l})$ & $\begin{array}{c}\text { Frequency of rooting } \\
(\%)\end{array}$ & $\begin{array}{c}\text { No. of roots/ } \\
\text { explant }\end{array}$ & $\begin{array}{c}\text { Root length } \\
(\mathrm{cm})\end{array}$ \\
\hline IAA & & & \\
0.5 & $46.93 \pm 2.63^{\mathrm{c}}$ & $3.57 \pm 0.20^{\text {cde }}$ & $3.48 \pm 0.11^{\text {cd }}$ \\
1.0 & $51.02 \pm 2.88^{\mathrm{c}}$ & $3.42 \pm 0.20^{\text {cde }}$ & $3.52 \pm 0.12^{\text {cd }}$ \\
1.5 & $51.02 \pm 2.88^{\mathrm{c}}$ & $2.85 \pm 0.26^{\mathrm{de}}$ & $3.30 \pm 0.04^{\text {cde }}$ \\
2.0 & $46.93 \pm 2.63^{\mathrm{c}}$ & $2.42 \pm 0.20^{\mathrm{e}}$ & $2.87 \pm 0.17^{\mathrm{e}}$ \\
IBA & & & \\
0.5 & $71.42 \pm 2.24^{\mathrm{b}}$ & $4.14 \pm 0.26^{\mathrm{c}}$ & $4.14 \pm 0.14^{\mathrm{b}}$ \\
1.0 & $63.26 \pm 2.88^{\mathrm{b}}$ & $6.57 \pm 0.29^{\mathrm{b}}$ & $3.68 \pm 0.10^{\mathrm{bc}}$ \\
1.5 & $91.83 \pm 4.24^{\mathrm{a}}$ & $12.85 \pm 0.82^{\mathrm{a}}$ & $5.11 \pm 0.28^{\mathrm{a}}$ \\
2.0 & $65.30 \pm 2.88^{\mathrm{b}}$ & $5.57 \pm 0.52^{\mathrm{bh}}$ & $3.47 \pm 0.11^{\mathrm{cd}}$ \\
NAA & & & \\
0.5 & $44.89 \pm 2.04^{\mathrm{c}}$ & $3.57 \pm 0.20^{\text {cde }}$ & $3.51 \pm 0.22^{\text {cd }}$ \\
1.0 & $46.93 \pm 2.63^{\mathrm{c}}$ & $4.00 \pm 3.77^{\mathrm{cd}}$ & $3.54 \pm 0.25^{\text {cd }}$ \\
1.5 & $42.85 \pm 3.11^{\mathrm{cd}}$ & $3.28 \pm 0.28^{\text {cde }}$ & $3.51 \pm 0.10^{\text {cd }}$ \\
2.0 & $34.76 \pm 1.82^{\mathrm{d}}$ & $2.57 \pm 0.20^{\mathrm{e}}$ & $3.02 \pm 0.18^{\mathrm{e}}$ \\
\hline
\end{tabular}

Values represent means \pm SE. Values followed by the same letter are not significantly different at $\mathrm{p}<0.05$ according to DMRT.

The present study demonstrates that axillary bud explants of Plectranthus bourneae are a good starting material for in vitro propagation. Combination of BA, TDZ and AdS was more effective in shoot multiplication and $\mathrm{GA}_{3}$ enhanced shoot elongation. Best rooting was achieved with IBA. IBA can be considered for root production in $P$. bourneae. The present micropropagation system can be recommended for the mass propagation of $P$. bourneae plants for conservation strategies. The acclimatized in vitro-derived plants can be used as an alternative to natural populations of $P$. bourneae.

\section{Acknowledgements}

The authors thank the authorities of the University Grants Commission, New Delhi for financial support in the form of major research project (UGC Ref. No. 
40-325/2011 (SR) dated 30.06.2011), and Mr. R.W. Stewart and Mrs. Tanya Balcar of Vattakanal Conservaton Trust, Kodaikanal for the help rendered during the field survey.

\section{References}

Abulfaith HA (1987) Medicinal plants in South-western Saudi Arabia, Al Thaghr Press: Khamis, p.162.

Awal SMA, Alam MJ, Ali MR and Hasan MNU (2005) In vitro propagation of pointed gourd (Trichosanthes dioica Roxb.) from shoot tips. Biotechnol. 4(3): 221-224.

Bown D (1995) Encyclopaedia of herbs and their uses. Dorling Kindersley, London.

Dhanasri G, Srikanth Reddy M, Naresh B and Cherku D (2013) Micropropagation of Salacia reticulate - An endangered medicinal plant. Plant Tissue Cult. Biotech. 23(2): 221-229.

Fatima M and Anis M (2012) Role of growth regulators on in vitro regeneration and histological analysis in Indian ginseng (Withania somnifera L.) Dunal. Physiol. Mol. Biol. Plants. 18(1): 59-67.

George EF, Hall MA and Klerk GJD (2007) Plant propagation by tissue culture. Springer Science \& Business Media. 1(6): 216.

Hemalatha P and Vadivel E (2010) Evaluation of in vitro seed germination and micropropogation techniques in Andrographis echioides (L.) Nees. Int. J. Agric. Sci. 6: 209-212.

Husain MK, Anis M and Shahzad A (2008) In vitro propagation of multipurpose leguminous tree (Pterocarpus marsupium Roxb.) using nodal explants. Acta. Physiol. Plant. 30:353-359.

Jayakumar S and Ramalingam R (2013) Influence of additives on enhanced in vitro shoot multiplication of Orthosiphon aristatus (Blume) Miq. Not. Sci. Biol. 5(3): 338-345.

Justin KY and Wilson S (2010) In vitro propagation of Graptophyllum pictum L. (Acanthaceae) - A medicinal plant. J. Biosci. 16:35-39.

Khattab S (2011) Effect of different media and growth regulators on the in vitro shoot proliferation of Aspen, hybrid Aspen and white Poplar male tree and molecular analysis of variants in micropropagated plants. Life Sci. J. 8(1): 177-184.

Lukhoba CW, Simmonds MSJ and Paton AJ (2006) Plectranthus: A review of ethnobotanical uses. J. Ethnopharmacol. 103: 1-24.

Marwah RG, Fatope MO, Deadmam ML, Ochei JE and Al-Saidi SH (2007) Antimicrobial activity and the major components of the essential oil of Plectranthus cylindraceus. J Appl. Microbiol. 103(4): 1220-1226.

Matthew KM (1993) Precursory notes on the flora of the Palni (Pulney) hills, South India: II Kew Bulletin 48: 757-765.

Matthew KM (1998) Suppl.III. Flora of Palni hills. 1117.

Matthew KM (1999) A report on the conservation status of south Indian plants. Biodiversity and Conservation 8: 779-796. 
Miller AG, Morris M and Suart S (1988) Plants of Dhofar, the Southern Region of Oman: Traditional, Economic and Medicinal Uses. Diwan of Royal Court, Sultanate of Oman: The office of the Advisor for Conservation of the Environment.

Mok DWS and Mok MC (2001) Cytokinin metabolism and action. Annu. Rev. Plnat Physiol Plant Mol Biol. 52:89-118.

Nagar S, Arora A, Singh VP, Ramakrishnan S, Umesh DK, Kumar S and Saini RP (2015) Effect of cytokinin analogues on cytokinin metabolism and stress responsive genes under osmotic stress in wheat. The Bioscan 10(1): 67-72.

Nayar MP, and Sastry ARK (1990) Red data book of Indian plants. Botanical survey of India, Calcutta. Vol. 1-3.

Rafique Ahamed MD, Anis M and Aref IM (2013). An efficient and reproducible method for in vitro propagation of Cassia alata L. - An important woody medicinal plant. Int J Pharm. Bio. Sci. 4(3): 1223-1234.

Rajani H and Patil SS (2009) In vitro response of different explants types on shoot and root development of ginger. Acta Hort. 829: 349-353.

Rivera Nunez D and Obon de Castro C (1992a) The ethnobotany of old world Labiateae. In: Harley RM, Reynolds T, eds. Advances in Labiate science. Kew: Royal Botanic Gardens. 455-473.

Rivera Nunez D and Obon de Castro C (1992b) Paleoethnobotany and archaeobotany of the Labiate in Europe and the Near East. In: Harley RM, Reynolds T, eds. Advances in Labiate science. Kew: Royal Botanic Gardens. 437-454.

Rout GR, Samantaray S and Das P (2000) In vitro manipulation and propagation of medicinal plants. Bioethanol. Adv. New York.18: .91-120.

Sharma S, Shahzad A, Ahamad A and Anjum L (2014) In vitro propagation and the acclimatization effect on the synthesis of 2-hydroxy-4methoxy benzaldehyde in Decalepis hamiltonii Wight and Arn. Acta Physiol. Plant 36: 2331-2344.

Shrivastava S and Banerjee M (2008) In vitro clonal propagation of physic nut (Jatropha curcas L.)- Influence of additives. Int. J. Integr. Biol 3: 73-79.

Sridhar TM, and Aswath CR (2014) Review on medicinal plants propagation: A comprehensive study on role of natural organic extracts in tissue culture medium. Am. J. Plant Sci. 5: 3073-3088.

Siwach P, and Gill AR (2011) Enhanced shoot multiplication in Ficus religiosa L. in the presence of adenine sulphate, glutamine and phloroglucinol. Physiol. Mol. Biol. Plants 17(3): 271-280.

Tawfik AA and Mohamed MF (2005) Organogenic response of Salvia officinals L. to dark preconditioning, thidiazuron and benzyladenine. Plant Growth Regul. Soc. Amer. Quarterly.33: 125-133.

Thangavel P, John Britto S and Senthilkumar SR (2011) Adventitious shoot regeneration from leaf explants of the valuable medicinal herb Plectranthus barbatus Andrews. Afr. J. Biotechnol. 10 (43): 8562-8569.

Vera R, Mondon JM, and Pieribattesti JC (1993) Chemical composition of the essential oil and aqueous extract of Plectranthus amboinicus. Planta Med. 59: 182-183. 